\title{
Estimation of Water Balance Components of Watersheds in the Manjira River Basin using SWAT Model and GIS
}

\author{
Akshata Mestry, Raju Narwade, Karthik Nagarajan
}

\begin{abstract}
This study mainly focus on hydrological behavior of watersheds in The Manjira River basin using soil and water assessment tool (SWAT) and Geographical information system (GIS). The water balance components for watersheds in the Manjira River were determined by using SWAT model and GIS. Determination of these water balance components helps to study direct and indirect factors affecting characteristics of selected watersheds. Manjira River contains total 28 watersheds among them 2 were selected having watershed code as MNJR008 and MNJR011 specified by the Central Ground Water Board. The SWAT input data such as Digital elevation model (DEM), land use and land cover (LU/LC), Soil classification, slope and weather data was collected. Using these inputs in SWAT the different water balancing components such as rainfall, baseflow, surface runoff, evapotranspiration (ET), potential evapotranspiration (PET) and water yield for each watershed were determined. The evaluated data is then validated by Regression analysis, in which two datasets were compared. Simulated rain data from SWAT simulation and observed rain data from Global Weather Data for SWAT was selected for comparison for each watershed.
\end{abstract}

Keywords - Water balance components, soil and water assessment tool (SWAT), Digital elevation model (DEM).

\section{INTRODUCTION}

W ater resource management has proven important factor from several aspects, such as irrigation, development of water-bodies for future needs, protection of water resources from pollution and also controlling quality as well as quantity of water. The different climatic conditions and human activities are changing water resource characteristics such as land cover, land use, soil condition, surface runoff and rainfall [1]. For effective water resource management first of all various hydrological components and water cycle must be studied and taken into consideration, which includes evapotranspiration, transpiration, condensation, precipitation and runoff. Water scarcity is most common problem in many countries throughout the world and so in India. To overcome this problem proper water resource management is essential.

Revised Manuscript Received on February 05, 2020.

* Correspondence Author

Akshata Mestry*, Department of Civil Engineering, Pillai HOC College of Engineering \& Technology, Rasayani, India.

E-mail: akshumestry17@gmail.com.

Raju Narwade, Department of Civil Engineering, Pillai HOC College

of Engineering \& Technology, Rasayani, India.

E-mail: rnarwade@mes.ac.in.

Karthik Nagarajan, Department of Civil Engineering, Pillai HOC College of Engineering \& Technology, Rasayani, India.

E-mail: knagaranjan@mes.ac.in.

(c) The Authors. Published by Blue Eyes Intelligence Engineering and Sciences Publication (BEIESP). This is an open access article under the CC BY-NC-ND license (http://creativecommons.org/licenses/by-nc-nd/4.0/)
The Marathwada region in Maharashtra, India faces water crisis every year due to depletion of water level. To find out the solution on such problems detailed study of water resources on smaller scale must be done [11].The study area includes two watersheds from Manar stream (watershed code-MNJR008 and MNJR011) [19]. These watersheds come under Manjira river which is the tributary of India's second largest river Godavari and flows through some parts of Marathwada region. The various GIS data such as soil data, LU/LC, DEM used as inputs in SWAT to determine water balance components of study area. The water balancing components helps in water budgeting, gives brief idea about watershed characteristics, this further can be used to predict the availability of water and so can help in water resource management.[14]

\section{LITERATURE REVIEW}

In this detailed literature survey was done to study and understand the different uses of SWAT, GIS and similar softwares in water management. With the help of SWAT model and geospatial techniques assessment of water balance of watershed in kurumali sub basin and Karuvannur river basin was done by Sandra George, Sathian and K.K. (2016) [13]. Frederick Ayivi and Manoj K Jha (2018) Estimated Water yield and water balance in Reedy ForkBuffalo creek watershed in North Carolina, they also assessed the performance of SWAT for future prediction of water balance and water yield in other watersheds of North Carolina [5]. Hayal Desta and Brook lemma (2017) quantified and compared water balance components, discharge of feeder river and evapotranspiration in Lake ziway watershed, Ethiopia using SWAT model[6]. O.M.M. Abdelwahab et al. (2018) compared simulation of soil erosion in Mediterranean watershed generated by two most widely used models, SWAT Soil and water assessment tool and Annualised agricultural Non-point source (AnnAGNPS) [10]. Muhammad adnan et al.(2019) quantified water budget of Nam Co lake by using SWAT (soil and water assessment tool coupled with DDM (Degree day model) over period of 2007 to 2013 [8]. David rivas-tabares(2019) assessed the water balance of cega-eresma-adaja watershed, they assessed land use in detail, water demand for period 20042014 of agricultural land using SWAT [4]. Natalja cerkasova et al.(2018) developed hydrology and water quality model for Nemunas large transboundaries watershed using SWAT, they used customized MATLAB scripts for HRU (hydrologic response unit) production also assessed SWAT model setup approaches for HRU definitions [9]. 
Aditya Nilawar and Milind Waikar (2019) quantified effects of climate change on sediment concentration and streamflow of Purna river basin in India by using SWAT [2]. Abeyou W. Worqlul et al. (2018) used SWAT model to evaluate hydrologic responses such as surface runoff response, water balance to soil characteristics for paired watershed in upper Blue Nile basin,

the study demonstrated sensitivity of watershed hydrology to soil [1]. Cesar Perez-validivia et al. (2017) investigated potential impact wetland drainage on hydrology i.e peak flow, annual volume of Pipestone creek watershed in cannada using SWAT [3]. Tao Can et al. (2015) used SWAT to simulate various land use scenarios and assessed the impact of it on water budgeting. They caliberated 12 model parameters and validated for 7 years for baseline conditions [15].

\section{OBJECTIVE}

The main aim of this study is to determine the water balance components of watersheds such as rain, runoff, water yield and evapotranspiration in the Manjira River basin by using SWAT and GIS.

\section{STUDY AREA}

The Manjira River is a tributary of Godavari River which is second largest river in India. Its origin is in balaghat range of hills near Ahmednagar district. This $724 \mathrm{~km}$ long river starts from Beed district then flows across Latur in Maharashtra state, Bidar in Karnataka state and finally in Telangana state. The Manjira River covers area about 30,844 Sqkm. The river has total six tributaries which are Terna, Tawarja, Gharni, Lendi, Manyad, Teru. There are total 28 watersheds in the Manjira river basin out of which two were selected. According to Central ground water board these watersheds are under Manar stream and coded as MNJR008 and MNJR011 respectively. Each of them is having area about 1550 and 957 Sqkm respectively. The watershed selected comes under Nanded district in Marathwada region. Fig 1 shows a map of watersheds selected for study

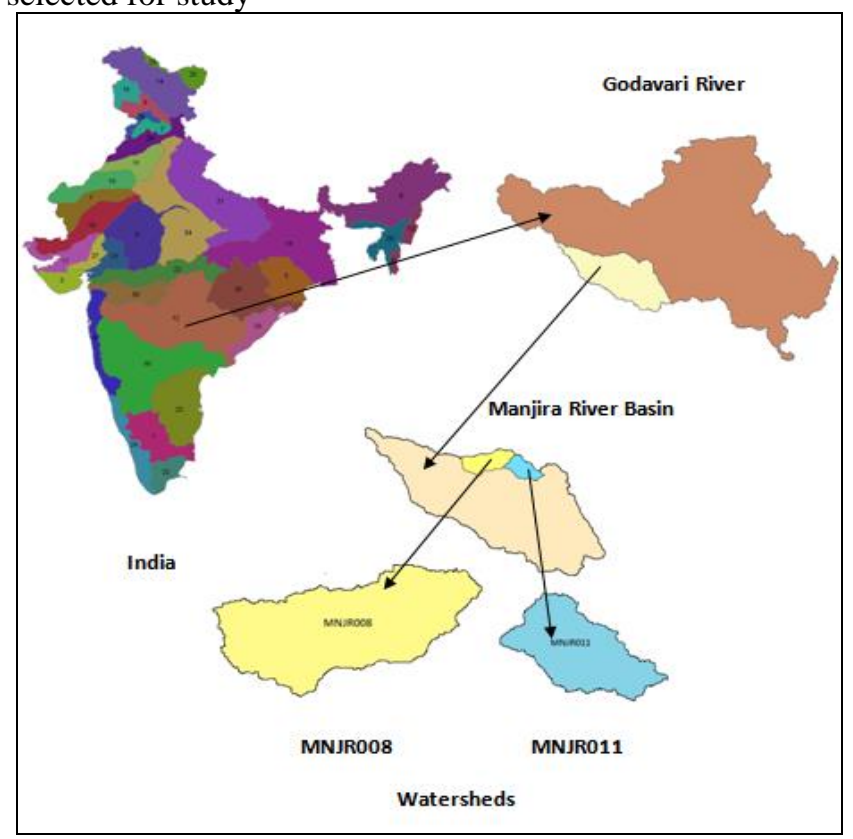

Fig 1. Study area (watershed MNJR008 and MNJR011)

\section{V.METHODOLOGY}

The flowchart showing methodology adopted for this study is given in Fig 2. The flowchart gives detail idea about method followed, input data and output received.Initially all the required input data was collected and prepared. The data was downloaded from USGS earth explorer to prepare DEM which is used as base map. The data downloaded for watersheds was of SRTM 1 Arc-Second Global Data. Also the shape files of respective watersheds were made which further used to prepare DEM of respective watershed.The data required to prepared shape file was collected from HydroSHEDS. The information regarding soil map was procured from official SWAT website in which Indian dataset is provided by Dr.Balaji Narasimhan .From Oak Ridge National Laboratory (ORNL) Distributed Active Archieve Centre (DAAC) the decadal landuse/landcover data at $100 \mathrm{~m}$ resolution for India at intervals 1985,1995 and 2005 was gathered. This data was procured from Indian Remote Sensing Satellites (IRS) Resourcesat Linear Imaging Self-Scanning Sensor-I or III (LISS-I, LISS-III) data, Landsat 4 and 5 Thematic Mapper (TM), Enhance Thematic Mapper Plus (ETM+), Multispectral (MSS) Data and visual interpretation and ground truth survey [16].

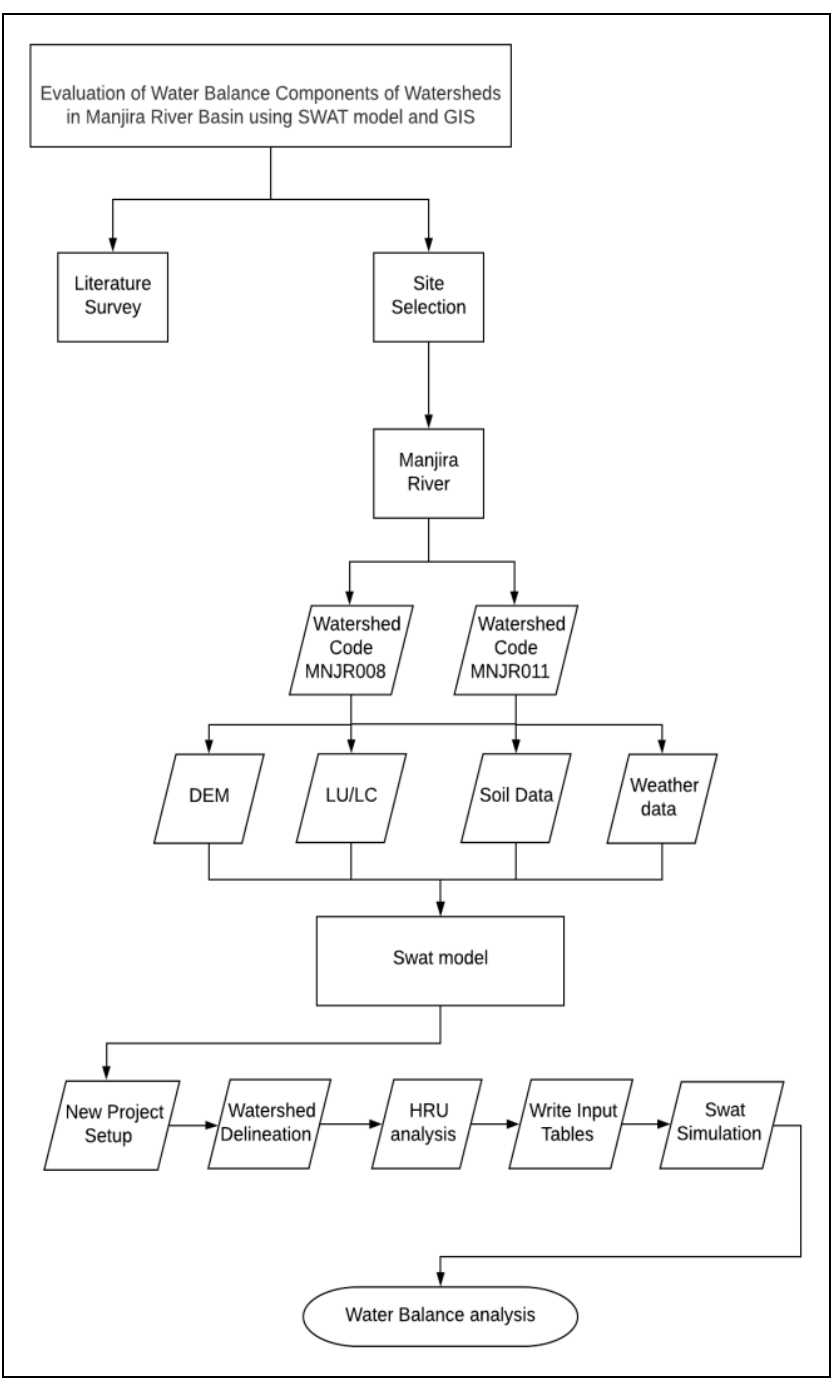

Fig 2. Flowchart of Methodology

\section{Published By:}




\section{SWAT MODEL}

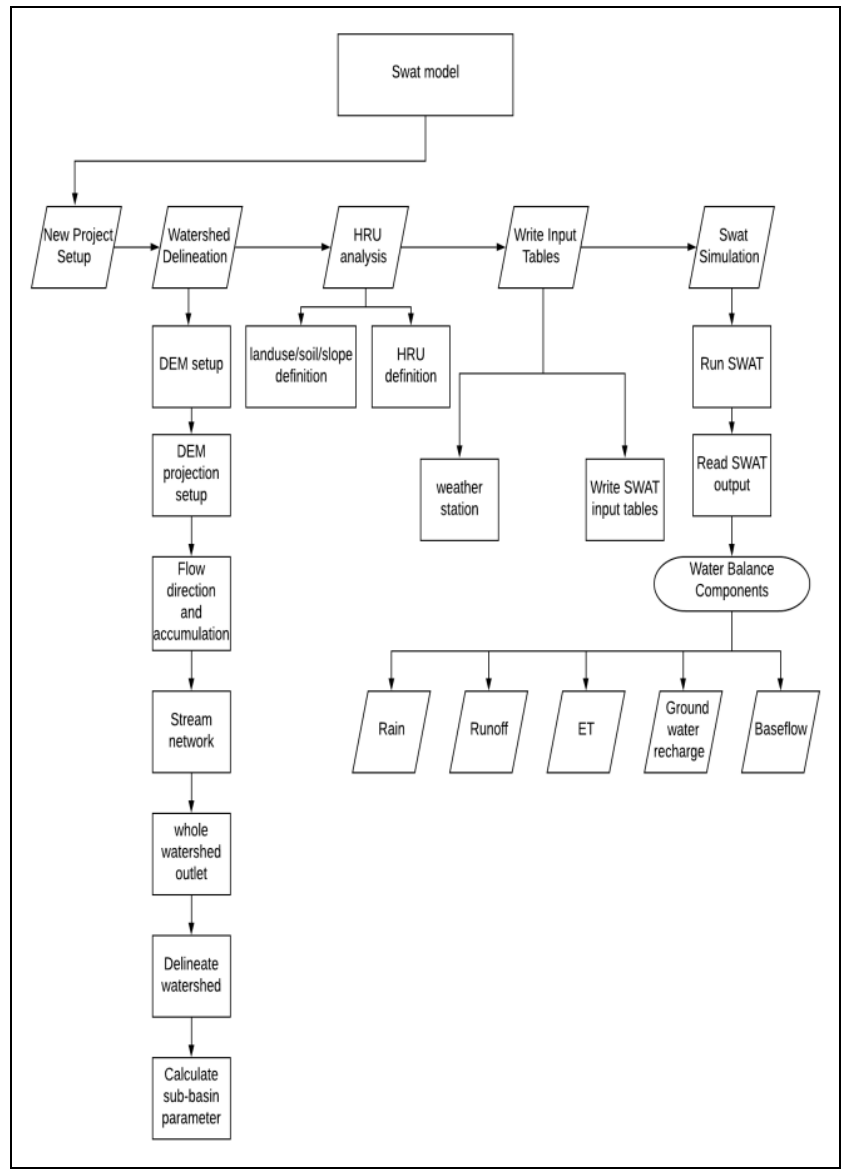

Fig 3. Flowchart of SWAT model

The SWAT means Soil and Water Assessment Tool, which is basin scale model extensively used to quantify water balance components. The steps involved in SWAT model setup has been given in flowchart shown in Fig 3. The input for SWAT model i.e SRTM DEM is corrected if any error, the DEM used was projected and corrected for watershed delineation. The topographic parameters of watershed were calculated.

For the HRU analysis land use/land cover, soil and slope data was collected from Indian dataset. The landuse/landcover,soil and slope map were prepared and Hydrological Response Unit was generated (HRU Unit).The model required weather data which was taken from Indian dataset. All the input tables for SWAT run are prepared by model. Then SWAT model is ready to run, by performing SWAT check and then read SWAT all the water balance components are determined.

\section{THEMATIC MAPS}

\section{A. Landuse/ Landcover}

Landuse and Landcover map showing distribution of land in watershed MNJR008 and MNJR011 in Manjira river basin have shown in Fig 4 and Fig 5,where WATR stands for Water, RNGB is for Rangeland brush, AGRL stands for Agricultural Land-Generic ,AGRR denotes Agricultural Land- Row Crops, AGRC is for Agricultural Land- close grown and FRST stands for Forest.

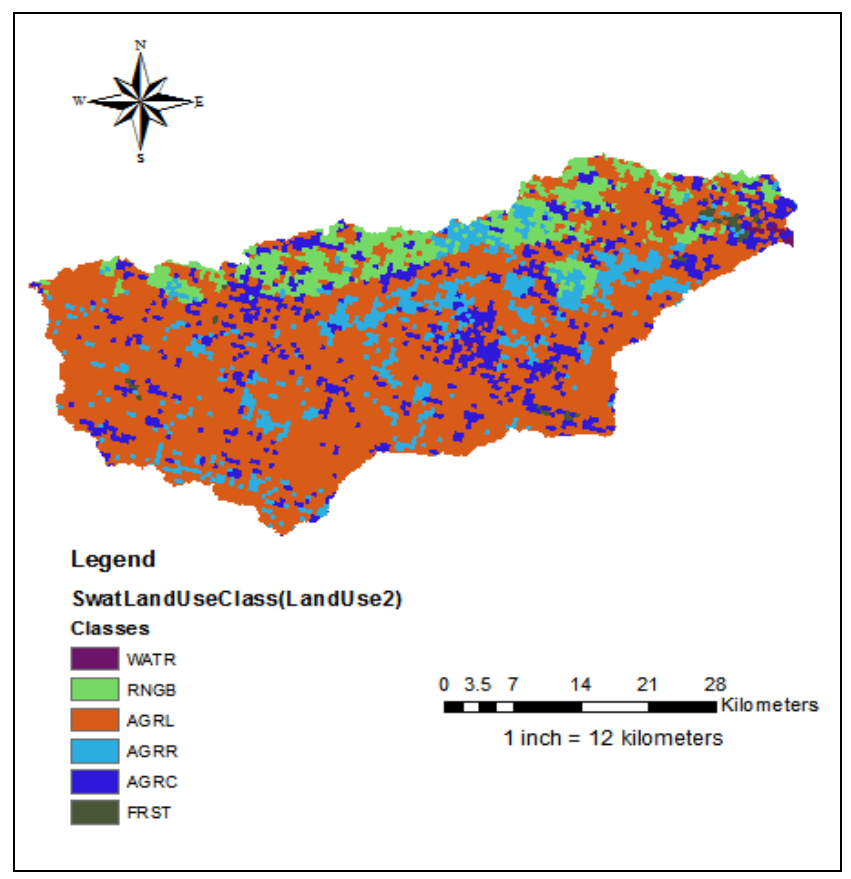

Fig 4: Landuse/landcover map of Manjira River Watershed (MNJR008)

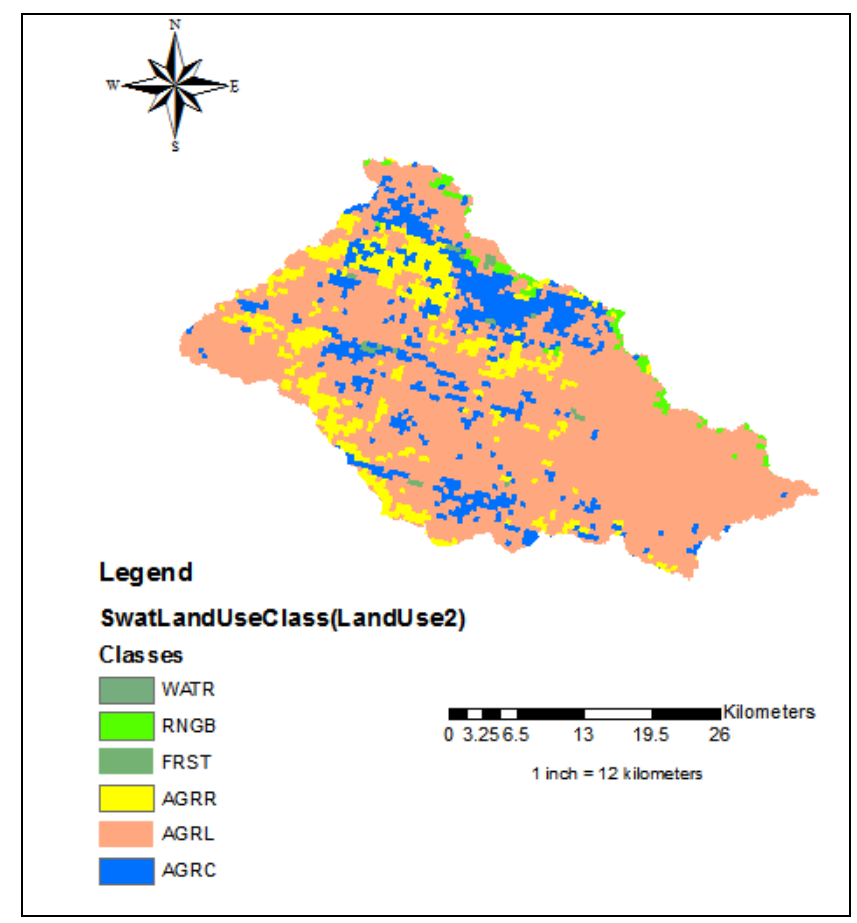

Fig 5. Landuse/landcover map of Manjira River Watershed (MNJR011)

\section{B. Soil map}

Soil Map of watershed MNJR008 and watershed MNJR011 in the Manjira river basin have shown in Fig 6 and Fig 7 respectively. In watershed MNJR008 there are three types of soils which are Clay-Loam, Clay and Clay and in Watershed MNJR011 there are two types of soils which are Clay-Loam and Clay shown in Table I.

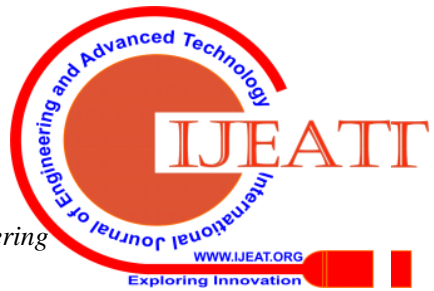




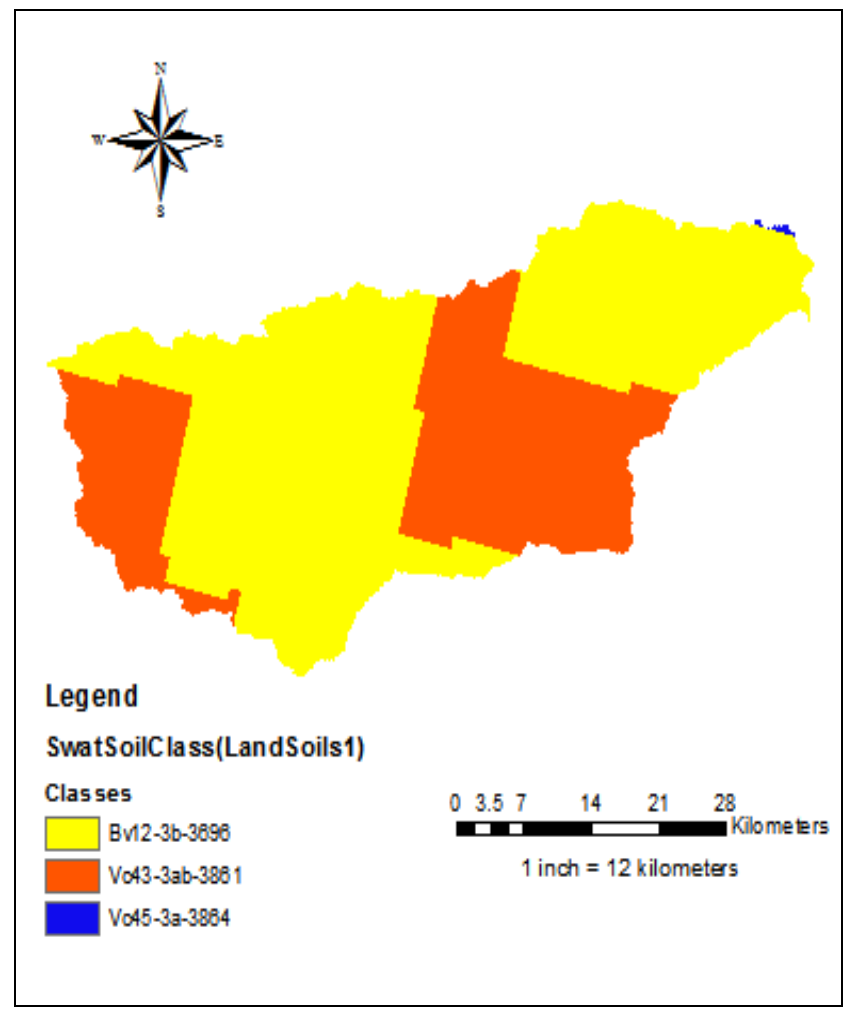

Fig 6: Soil map of Manjira River Watershed (MNJR008)

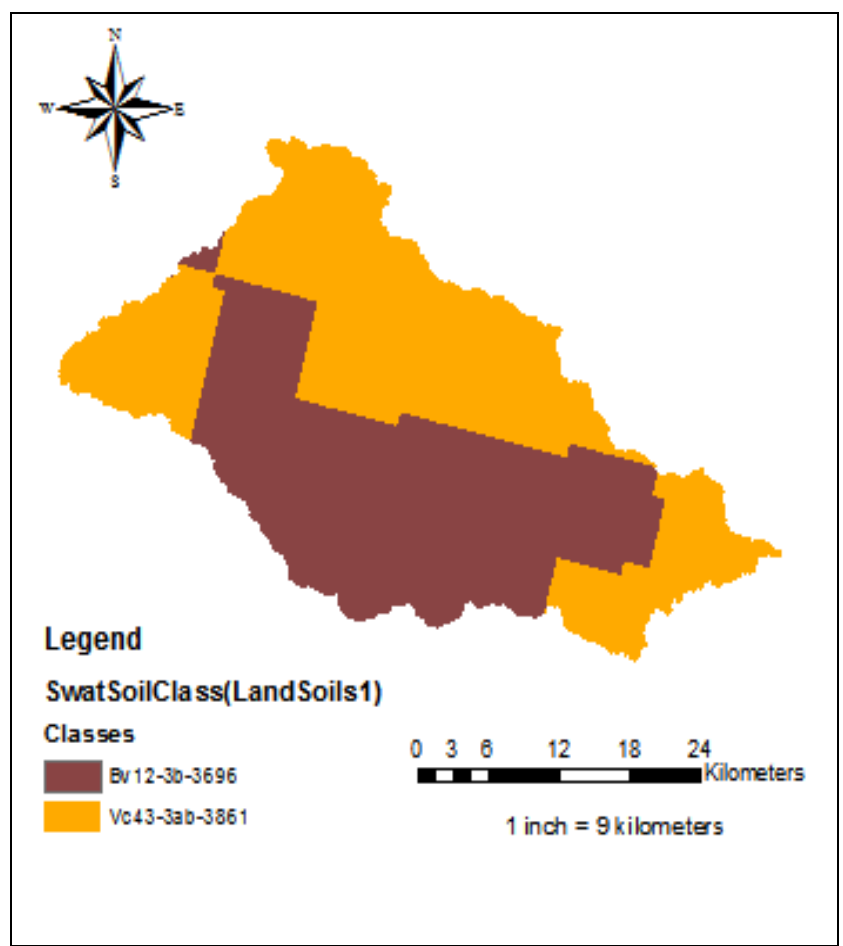

Fig 7. Soil map of Manjira River Watershed (MNJR011)

Table I: Soil Taxonomy

\begin{tabular}{|l|l|}
\hline Bv12-3b-3696 & CLAY_LOAM \\
\hline Vo43-3ab-3861 & CLAY \\
\hline Vo45-3a-3864 & CLAY \\
\hline
\end{tabular}

\section{Digital Elevation Map}

Digital Elevation Model (DEM) of watershed MNJR008 and MNJR011 in Manjira river basin have shown in Fig 8 and Fig 9 respectively.

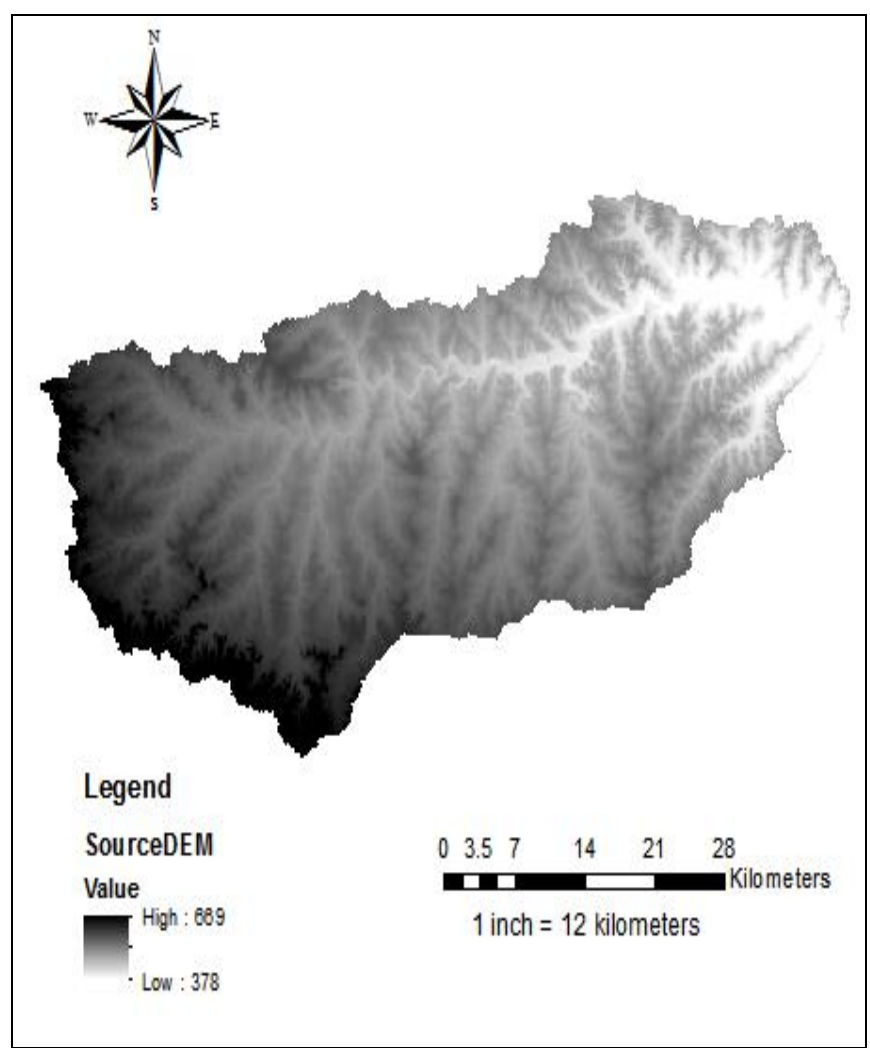

Fig 8: Digital Elevation of Manjira River Watershed (MNJR008)

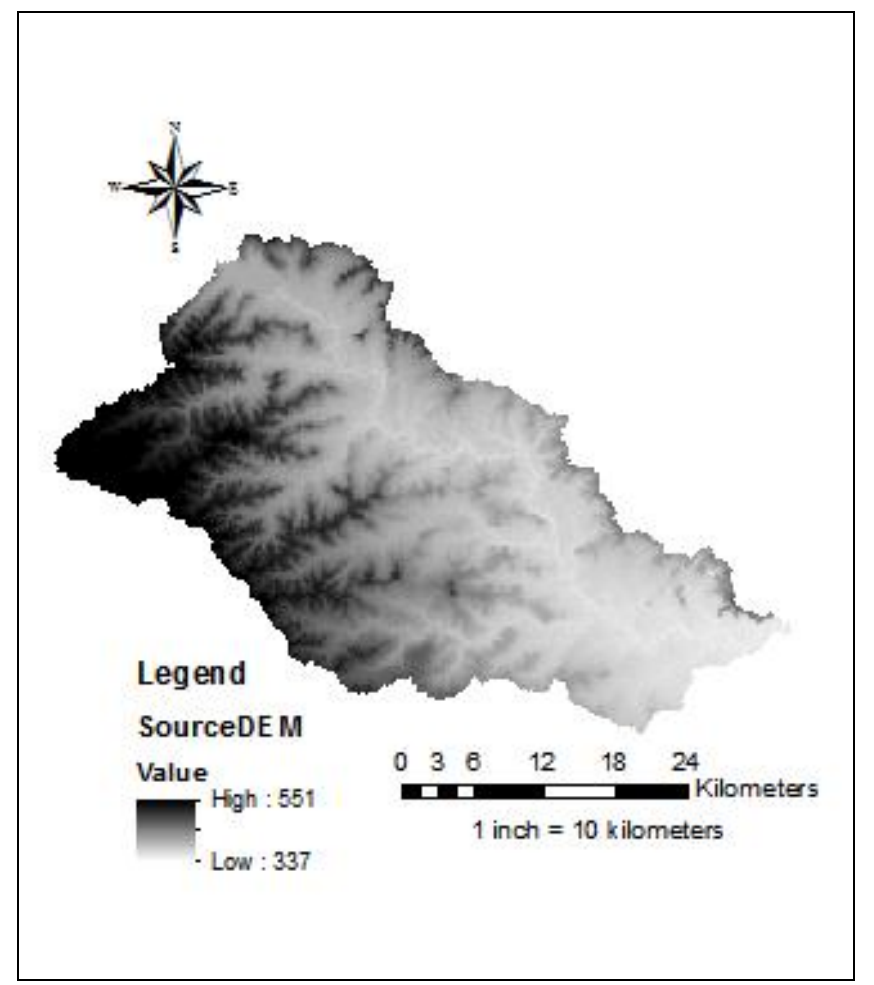

Fig 9: Digital Elevation of Manjira River Watershed (MNJR011)

Published By:

Blue Eyes Intelligence Engineering \& Sciences Publication

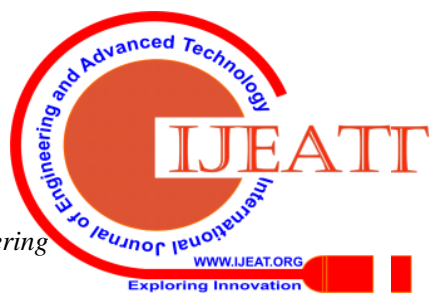




\section{RESULTS}

The various Water Balancing Components have been generated using SWAT model. The components which determined are Rainfall, ET, Runoff, Baseflow, Ground water recharge. The landuse and landcover distribution in study area was also given by SWAT model. It has also provided landuse/lancover and soil maps. soil maps show the soil classification across the study region. The SWAT simulation was used separately for each watershed, so we have two water balancing equation for each watershed. The water balance equation is as follows:

$\mathrm{P}-\mathrm{Q}-\mathrm{ET}-$ Base flow $\pm \Delta \mathrm{TWS}-$ (other components) $=0$ .........(equation 1)

Where;

$\mathrm{P}=$ Precipitation

$\mathrm{Q}=$ Runoff

$\mathrm{E}=$ Evapotranspiration

$\Delta \mathrm{TWS}=$ change in terrestrial water storage

And other components consist soil moisture, shallow and deep ground water storage, glacier and soil moisture. [12]

\section{A.Watershed MNJR008:}

The SWAT output for Watershed MNJR008 is shown in Fig 10. The Fig shows water balancing components in watershed and its values.

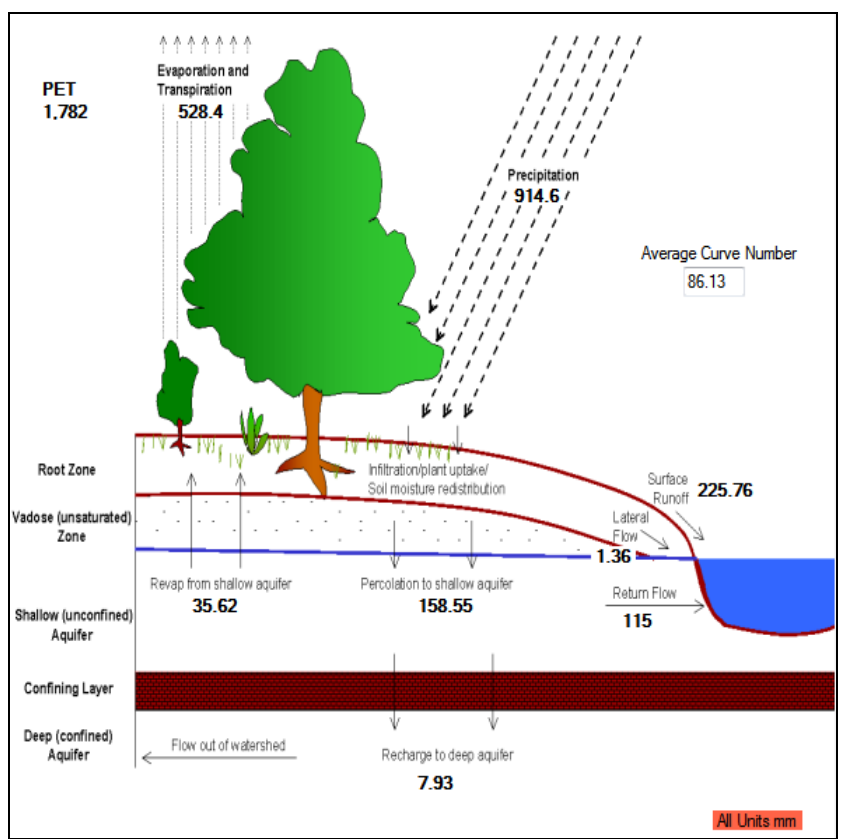

Fig 10: Water balance Components of the Manjira Watershed MNJR008

According to output the Average precipitation $=914.6 \mathrm{~mm}$, Average total Runoff (surface+lateral+return) $=342.12$ $\mathrm{mm}$,

Average ground water recharge $=7.93 \mathrm{~mm}$ and

Average Evapotranspiration

So from equation 1 ;

$$
914.6 \text { - } 342.12-528.4-7.93=36.15
$$

The value 36.15 includes other components such as interception, shallow and deep ground water storage also soil moisture and snow, glaciers.

Therefore,

$$
914.6-342.12-528.4-7.93-36.15=0
$$

This equation shows water balance is equal to zero which means the incoming water in the MNJR008 watershed region is equal to the outgoing water in same region. Table 2 shows value of water entering and leaving watershed MNJR008 region which is equal.

Table II: Water Balance Components of watershed MNJR008

\begin{tabular}{|c|c|c|}
\hline $\begin{array}{c}\text { Water Balance } \\
\text { Component }\end{array}$ & $\begin{array}{c}\text { Incoming } \\
\mathbf{( m m )}\end{array}$ & $\begin{array}{c}\text { Outgoing } \\
\mathbf{( m m )}\end{array}$ \\
\hline Precipitation & 914.6 & - \\
\hline ET & - & 528.4 \\
\hline Runoff & - & 342.12 \\
\hline Other components & - & 36.15 \\
\hline Groundwater recharge & - & 7.93 \\
\hline Total & $\mathbf{9 1 4 . 6}$ & $\mathbf{9 1 4 . 6}$ \\
\hline
\end{tabular}

The monthly Basin values for watershed MNJR008 of Manjira River was derived by SWAT simulation, which is shown in Table III.

Table III: Monthly basin value of the Manjira Watershed MNJR008

\begin{tabular}{|c|c|c|c|c|}
\hline Month & $\begin{array}{c}\text { Rain } \\
\mathbf{( m m})\end{array}$ & $\begin{array}{c}\text { Runoff } \\
\mathbf{( m m})\end{array}$ & $\begin{array}{c}\text { Water } \\
\text { yield(mm) }\end{array}$ & $\begin{array}{c}\text { ET } \\
\mathbf{( m m})\end{array}$ \\
\hline 1 & 0.1 & 0.12 & 2.27 & 12.76 \\
\hline 2 & 1.67 & 0.38 & 1.04 & 8.21 \\
\hline 3 & 11.03 & 1.41 & 1.92 & 43.41 \\
\hline 4 & 9.21 & 0.11 & 0.5 & 48.66 \\
\hline 5 & 25.93 & 0.23 & 0.52 & 25.09 \\
\hline 6 & 145.97 & 7.94 & 7.53 & 64.21 \\
\hline 7 & 199.1 & 45.33 & 45.98 & 71.08 \\
\hline 8 & 197.45 & 67.45 & 78.3 & 73.23 \\
\hline 9 & 182.44 & 64.77 & 91.1 & 69.45 \\
\hline 10 & 109.08 & 31.07 & 70.2 & 59.83 \\
\hline 11 & 24.9 & 5.34 & 34.84 & 32.51 \\
\hline 12 & 7.93 & 3.03 & 15.94 & 20.26 \\
\hline
\end{tabular}

Table III gives average monthly values of precipitation, runoff, water yield and ET for watershed MNJR008 of Manjira River. The graphical representation of these components is shown in Fig 11, 12, 13, 14 respectively. 


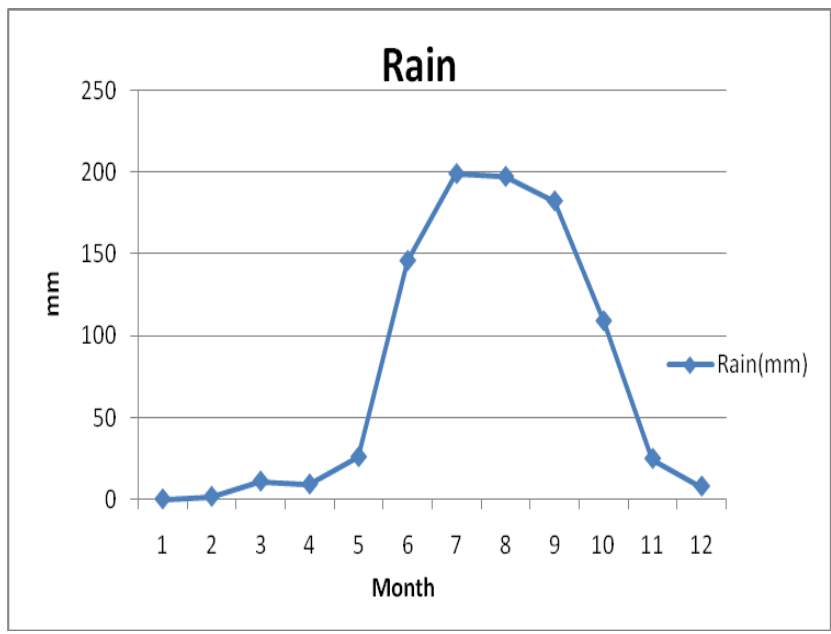

Fig 11: Average monthly rainfall for the Manjira River watershed MNJR008

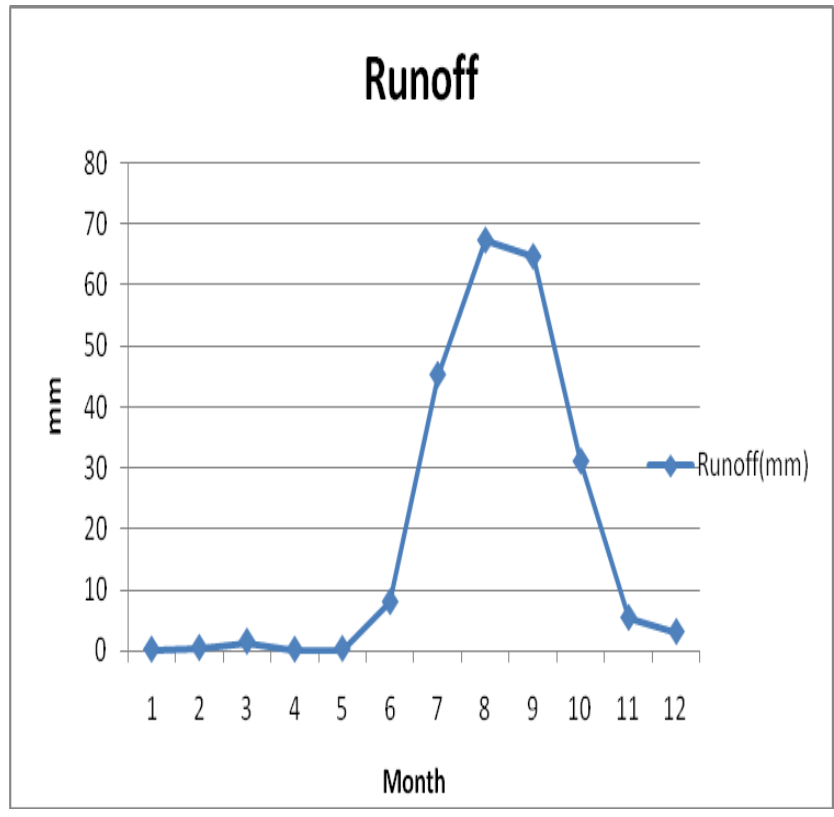

Fig 12: Average monthly runoff for Manjira River watershed MNJR008

\section{Water yield}

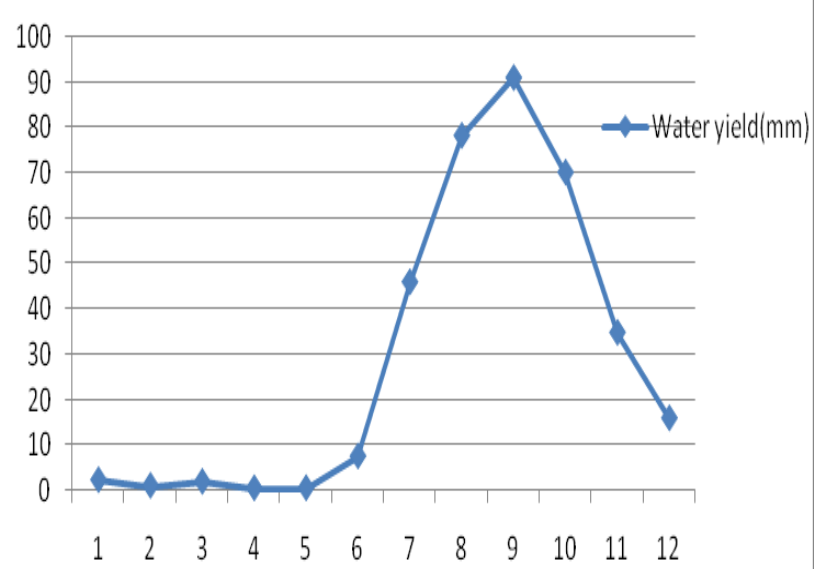

Fig 13: Average monthly water yield for the Manjira River watershed MNJR008

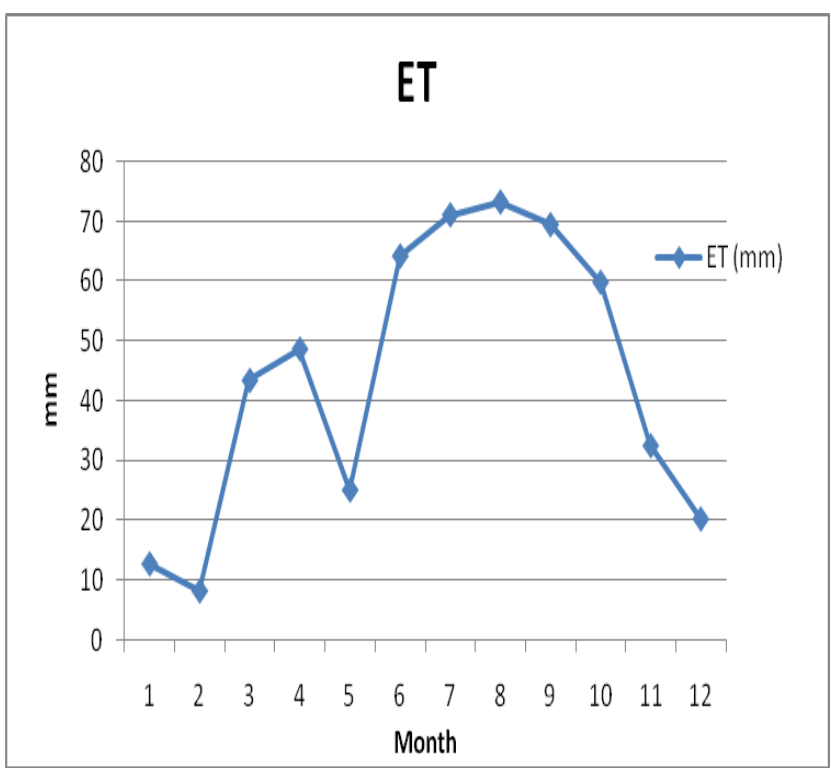

Fig 14: Average monthly evapotranspiration for the Manjira the River watershed MNJR008

\section{B. Watershed MNJR011:}

The SWAT output for Watershed MNJR011 is shown in Fig 15. The fig shows water balancing components in watershed and its values.

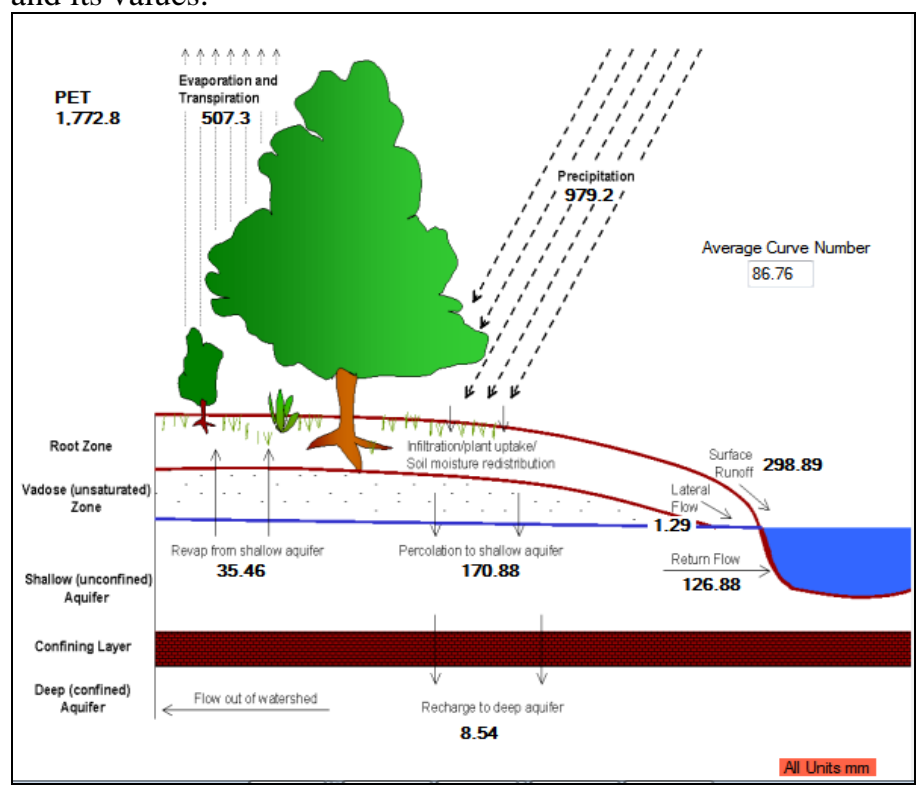

Fig 15: Water balance Components of the Manjira Watershed MNJR011

According to output the Average precipitation $=979.2 \mathrm{~mm}$, Average total Runoff (surface+lateral+return) $=427.06 \mathrm{~mm}$, Average ground water recharge $=8.54 \mathrm{~mm}$ and Average Evapotranspiration $=507.3 \mathrm{~mm}$. From equation 1;

$$
979.2-427.06-507.3-8.54=36.3
$$

The value 36.3 includes other components such as interception, shallow and deep ground water storage also soil moisture and snow, glaciers.

Therefore,

Published By:

Blue Eyes Intelligence Engineering

Retrieval Number: C6431029320/2020@BEIESP

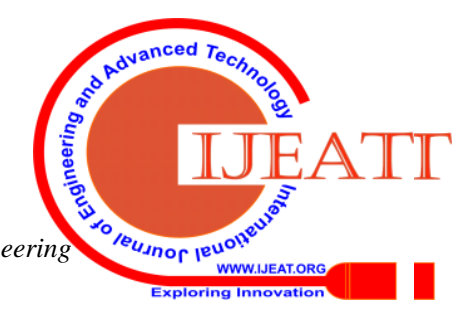


$979.2-427.06-507.3-8.54-36.3=0$

This equation shows water balance is equal to zero which means the incoming water in the MNJR011 watershed region is equal to the outgoing water in same region. Table IV shows value of water entering and leaving watershed MNJR011 region which is equal.

Table IV: Water Balance Components of watershed MNJR011

\begin{tabular}{|c|c|c|}
\hline Water Balance Component & $\begin{array}{c}\text { Incoming } \\
\mathbf{( m m )}\end{array}$ & $\begin{array}{c}\text { Outgoing } \\
\mathbf{( m m )}\end{array}$ \\
\hline Precipitation & 979.2 & \\
\hline ET & - & 507.3 \\
\hline Runoff & - & 427.06 \\
\hline Other components & - & 36.3 \\
\hline Groundwater recharge & - & 8.54 \\
\hline Total & $\mathbf{9 7 9 . 2}$ & $\mathbf{9 7 9 . 2}$ \\
\hline
\end{tabular}

The monthly Basin values for watershed MNJR011 of the Manjira River was derived by SWAT simulation which is given in Table $\mathrm{V}$.

Table V: Monthly basin value of the Manjira Watershed MNJR011

\begin{tabular}{|c|c|c|c|c|}
\hline Month & $\begin{array}{c}\text { Rain } \\
(\mathbf{m m})\end{array}$ & Runoff(mm) & $\begin{array}{c}\text { Water yield } \\
(\mathbf{m m})\end{array}$ & ET (mm) \\
\hline 1 & 0.10 & 0.11 & 1.89 & 11.29 \\
\hline 2 & 0.17 & 0.10 & 0.78 & 6.71 \\
\hline 3 & 12.83 & 1.94 & 2.50 & 41.50 \\
\hline 4 & 9.26 & 0.15 & 0.55 & 48.37 \\
\hline 5 & 20.17 & 0.26 & 0.57 & 19.83 \\
\hline 6 & 157.66 & 14.82 & 13.97 & 61.37 \\
\hline 7 & 224.25 & 68.00 & 68.58 & 70.72 \\
\hline 8 & 228.08 & 89.53 & 105.49 & 73.62 \\
\hline 9 & 165.90 & 59.72 & 92.91 & 68.44 \\
\hline 10 & 125.38 & 53.23 & 93.82 & 54.38 \\
\hline 11 & 31.82 & 10.08 & 39.74 & 31.81 \\
\hline 12 & 3.74 & 2.28 & 14.97 & 19.53 \\
\hline
\end{tabular}

The table gives average monthly values of precipitation, runoff, water yield and ET for Watershed MNJR011 in Manjira River.
The graphical representation of these components is shown in Fig 16, 17, 18, 19 respectively

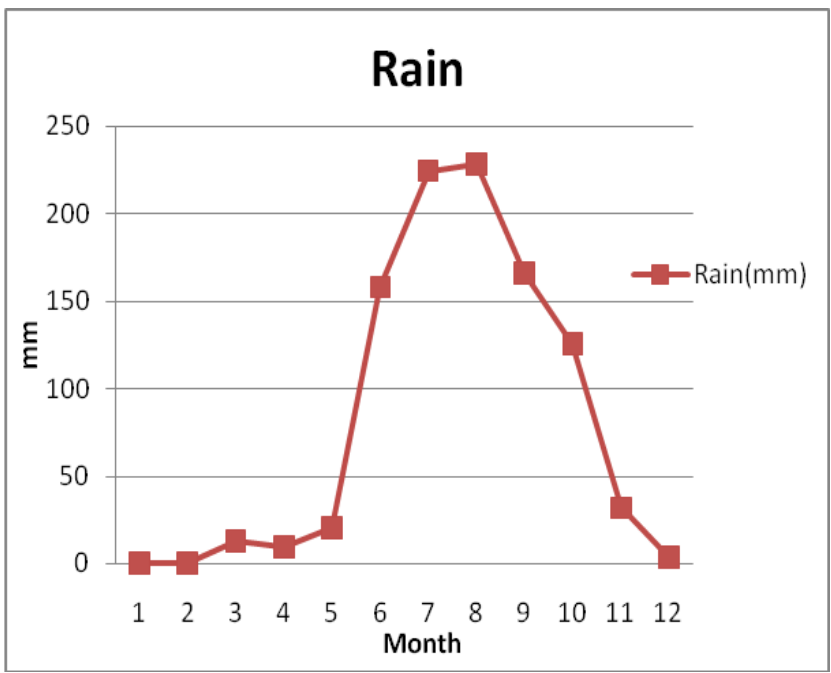

Fig 16. Average monthly Rainfall for the Manjira River watershed MNJR011

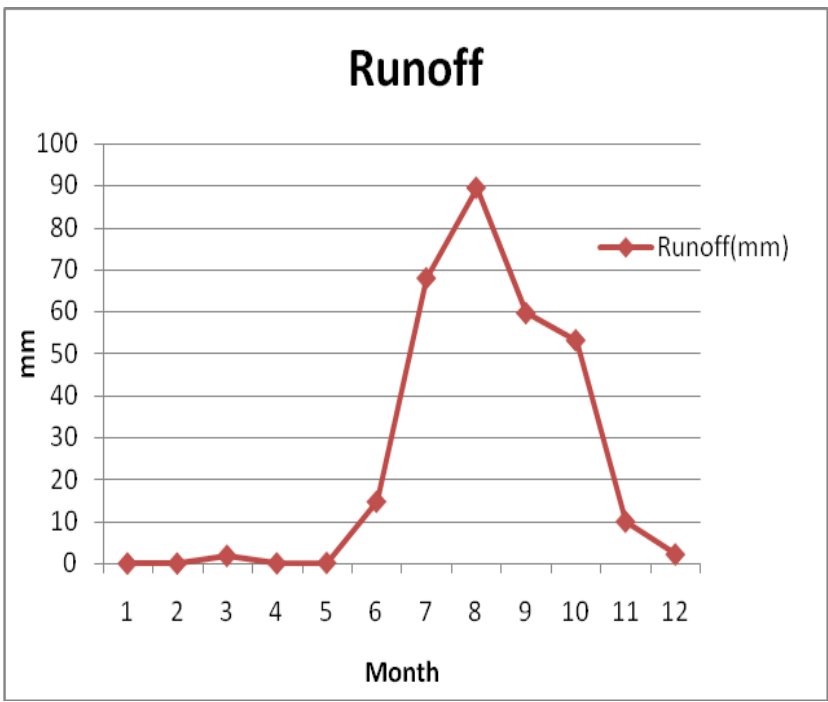

Fig 17. Average monthly Runoff for the Manjira River watershed MNJR011

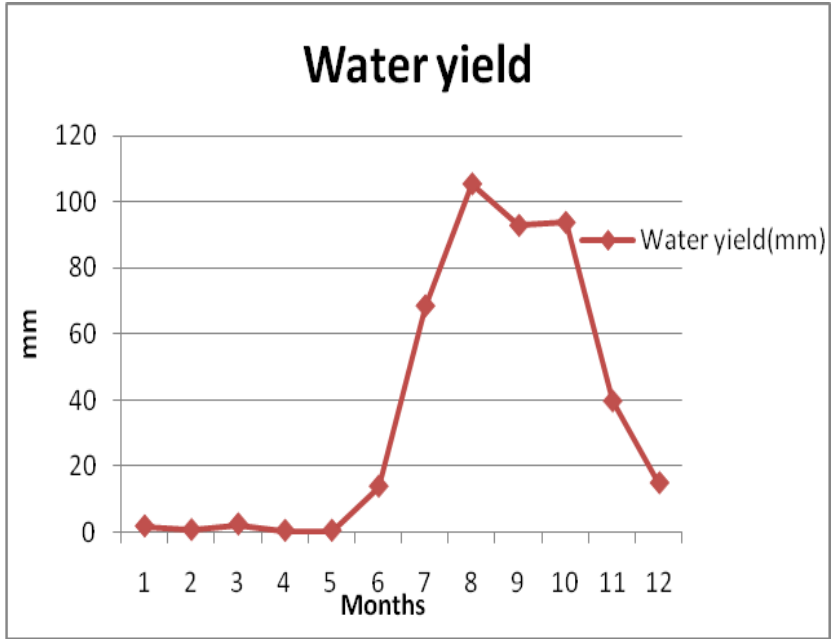

Fig 18. Average monthly water yield for the Manjira River watershed MNJR011

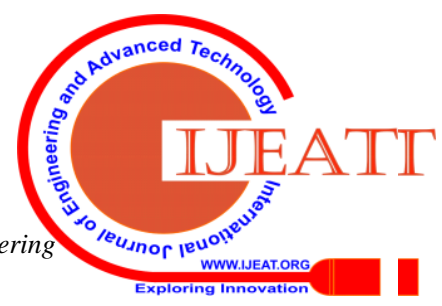




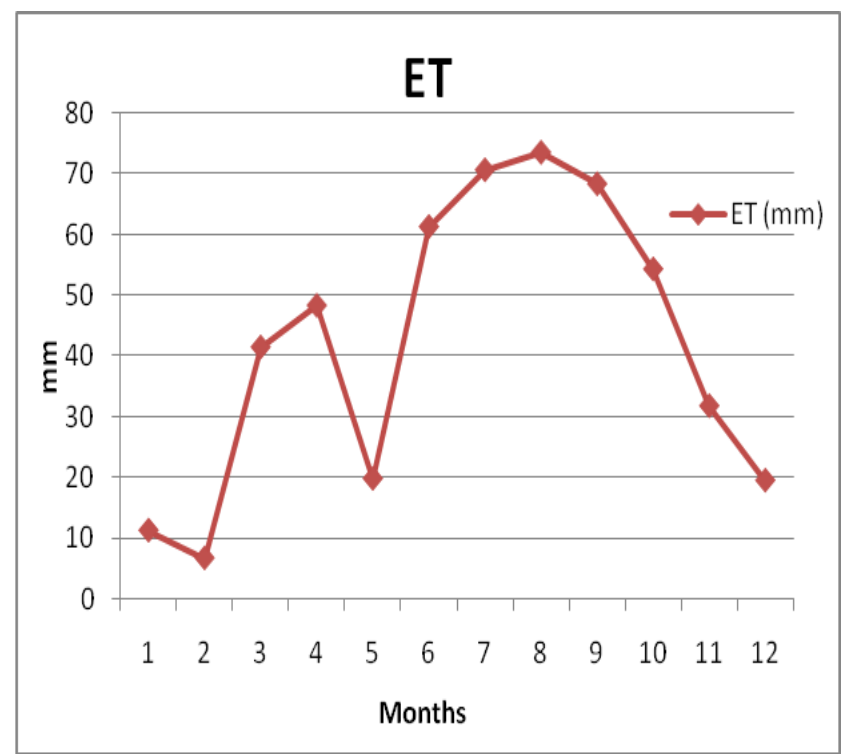

Fig 19. Average monthly evapotranspiration for the Manjira River watershed MNJR011

Modelling results gave us various Water balance components of the Manjira River Watersheds, which gives us brief idea about water availability for use hence which can be prove helpful in effective water resource management and allocation of water for different purposes in study region.

\section{VALIDATION}

The simulated water balance data from SWAT is compared with the observed data which was taken from Global weather Data for SWAT. The simulated and observed rain data was taken for comparison for both the watersheds. To validate the obtained result regression analysis was performed. The value for coefficient of determination i.e $\mathrm{R}^{2}$ was found for both watersheds. The coefficient of determination $\mathrm{R}^{2}$ ranges between 0 to 1 . It is considered that if the value of $\mathrm{R}^{2}$ is closer to 1 then the similitude between the two dataset is more.

\section{A.Watershed MNJR008:}

The regression analysis was performed for the simulated and observed rain data of the watershed MNJR008. Table VI shows monthly simulated and observed data for watershed MNJR008. Fig 20 shows the graphical representation between simulated and observed rain data for watershed MNJR008 of the Manjira River.

Table VI: Average monthly simulated and observed rain data for MNJR008 watershed

\begin{tabular}{|c|c|c|}
\hline Month & Simulated & Observed \\
\hline January & 0.1 & 4.23 \\
\hline February & 1.67 & 2.64 \\
\hline March & 11.03 & 11.53 \\
\hline April & 9.21 & 7.05 \\
\hline May & 25.93 & 15.36 \\
\hline June & 145.97 & 163.88 \\
\hline July & 199.1 & 206.35 \\
\hline August & 197.45 & 264.55 \\
\hline September & 182.44 & 241.3 \\
\hline October & 109.08 & 87.22 \\
\hline November & 24.9 & 39.75 \\
\hline December & 7.93 & 2.51 \\
\hline
\end{tabular}

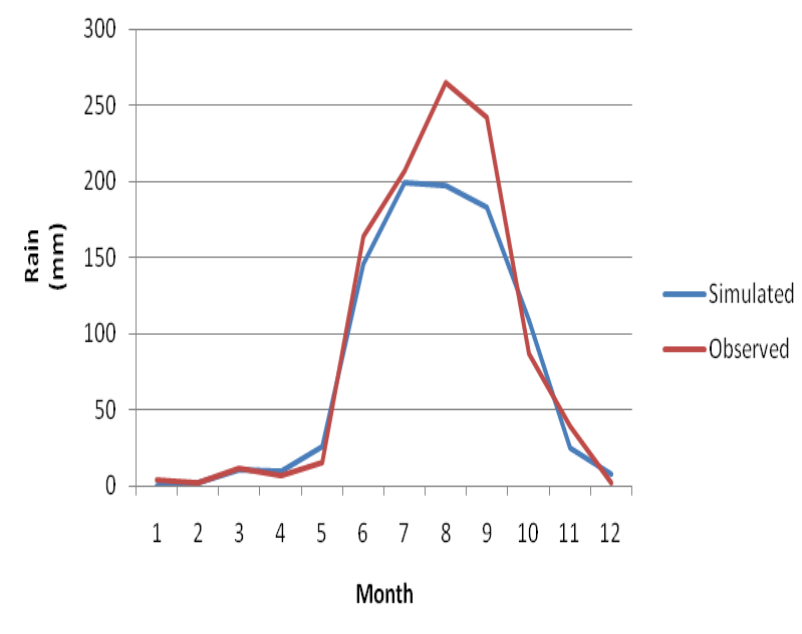

Fig 20. Comparison between Simulated and observed rain data for MNJR008 watershed

Table VII shows summary of regression analysis $\left(\mathrm{R}^{2}\right)$ between simulated and observed rain dataset. The value of $\mathrm{R}^{2}$ was found to be 0.9566 .

Table VII: Regression analysis for MNJR008 watershed

\begin{tabular}{|l|r|}
\hline \multicolumn{2}{|c|}{ SUMMARY OUTPUT } \\
\hline \multicolumn{2}{|c|}{ Regression Statistics } \\
\hline Multiple R & 0.980119184 \\
\hline R Square & 0.960633614 \\
\hline Adjusted R Square & 0.956696975 \\
\hline Standard Error & 17.40383048 \\
\hline Observations & 12 \\
\hline
\end{tabular}

\section{B. Watershed MNJR011:}

The regression analysis was performed for the simulated for and observed rain data of the watershed MNJR011.

Table VIII shows monthly simulated and observed data for watershed MNJR011. Fig 21 shows the graphical representation between simulated and observed rain data for watershed MNJR011 of the Manjira River.

Table VIII: Average monthly simulated and observed rain data for MNJR011 watershed

\begin{tabular}{|c|c|c|}
\hline Month & Simulated & Observed \\
\hline January & 0.1 & 13.27 \\
\hline February & 0.17 & 10.16 \\
\hline March & 12.83 & 12.26 \\
\hline April & 9.26 & 7.37 \\
\hline May & 20.17 & 14.62 \\
\hline June & 157.66 & 163.92 \\
\hline July & 224.25 & 206.4 \\
\hline August & 228.08 & 255.49 \\
\hline September & 165.9 & 238.76 \\
\hline October & 125.38 & 85.64 \\
\hline November & 31.82 & 31.19 \\
\hline December & 3.74 & 2.17 \\
\hline
\end{tabular}




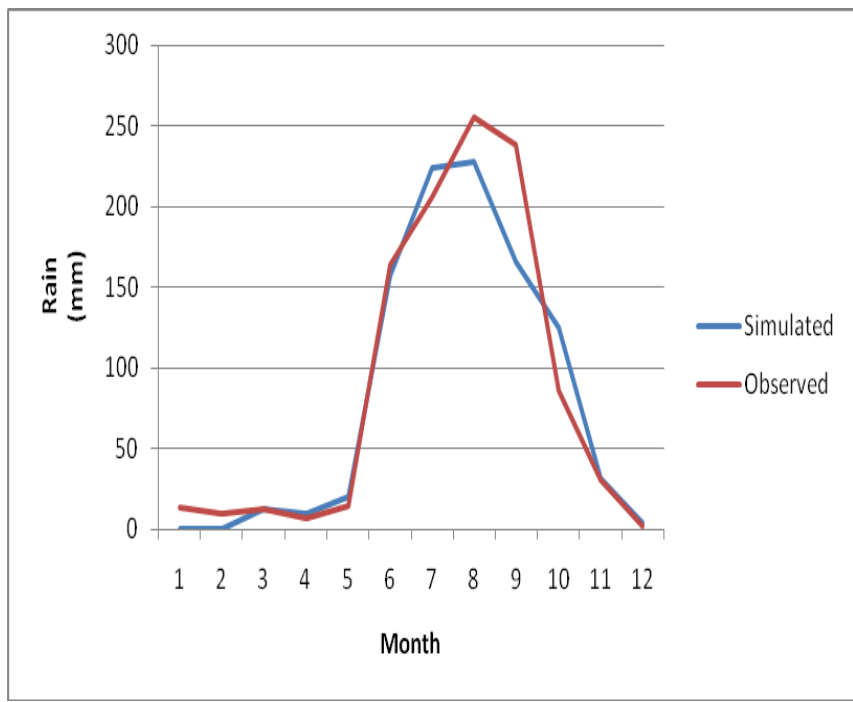

Fig 21. Comparison between Simulated and observed rain data for MNJR011 watershed

Table IX shows summary of regression analysis between simulated and observed rain dataset. The value of $\mathrm{R}^{2}$ i.e Coefficient of was found to be 0.9232 .

Table IX: Regression analysis for MNJR011 watershed

\begin{tabular}{|l|r|}
\hline \multicolumn{2}{|c|}{ SUMMARY OUTPUT } \\
\hline \multicolumn{2}{|c|}{ Regression Statistics } \\
\hline Multiple R & 0.964486059 \\
\hline R Square & 0.930233358 \\
\hline Adjusted R Square & 0.923256694 \\
\hline Standard Error & 25.35726296 \\
\hline Observations & 12 \\
\hline
\end{tabular}

\section{CONCLUSION}

In this study the different water balancing components of two watersheds in the Manjira River was evaluated with the help of SWAT and GIS. To validate the evaluated data regression analysis was performed between simulated data and observed data from Global weather Data for SWAT for each watershed. The value of $\mathrm{R}^{2}$ was obtained for watershed MNJR008 and MNJR011 is 0.9566 and 0.9232 respectively, which shows the data evaluated from SWAT simulation is similar to observed data. This data can be used for various water resource management programs. This gives brief idea about different watershed characteristics. The water yield obtained tells us about the actual usable water available. Futher research can be done to allocate and distribute this available water.

\section{CONFLICT OF INTEREST STATEMENT}

On behalf of all the authors, the corresponding author states that there is no conflict of interest.

\section{REFERENCES}

1. Abeyou W. Worqlula, Essayas K. Ayanab , Haw Yena , Jaehak Jeonga , Charlotte Macalisterc , Robin Taylora, Thomas J. Gerika , Tammo S. Steenhuisd "Evaluating hydrological responses to soil characteristics using SWAT model in a paired-watersheds in the Upper Blue Nile Basin,’in Catena, vol. 163, pp.332-341, April 2018.

2. Aditya P. Nilawar and Milind L. Waikar, "Impactsof climate change on streamflow and sediment concentration under RCP 4.5 and 8.5: A case study in Purna river basin, India" in Science of total environment, vol. 650, Part 2, pp. 2685-2696, February 2019.
3. CesarPerez-Valdiviaa, Barbara Cade-Menumb and Dena W. McMartina, "Hydrological modeling of the pipestone creek watershed using soil and water assessment tool (SWAT): Assessing impacts of wetland drainage on hydrology," in Journal of Hydology:Regional studies, vol.14, pp. 109-129, December 2017.

4. David Rivas-Tabaresa, Ana M. Tarquisa, Barbara Willaarts, Angel De Miguel, "An accurate evaluation of water availability in sub-arid Mediterranean Watershed through SWAT-Cega-Eresma-Adaja," Agricultural Water Management, vol. 212, pp. 211-225, February 2019.

5. Frederick Ayivi and Manoj K. Jha, "Estimation of Water Balance and Water Yield in Reedy Fork-Buffalo Creek Watershed in North Carolina using SWAT," International Soil and water conservation Research, vol. 6, pp. 203-213, September 2018.

6. Hayal Desta and Brook Lemma, "SWAT based hydrological assessment and characterization of lake Ziway, sub-watersheds, Ethiopia," in Journal of Hydrology: Regional studies, vol.13, pp.122 137, October 2017.

7. Jaykrishnan R. Shrinivasan R., Santhi C. and Arnold J. G. in "Advances in application in SWAT model for water resource management”,Hydrological Processes, 19(3), pp. 749-762.

8. Muhammad Adnan, Shichang Kang Guoshuai Zhang, Muhammad Saifulla, MuhammadNaveen Anjum and Ayaz Fateh Ali, "Simulation and analysis of the water balance of the Nam Co Lake using SWAT model," in Water, vol.11, Issue 7, July 2019.

9. Natalja Cerkasova,Georg Umgiesser and Ali Erturc, Development of a hydrology and water quality model for transboundary river watershed to investigate the impact of climate change, in Ecological Engineering, vol.124, pp.99-115, December 2018.

10. O.M.M. Abdelwahaba, G.F. Riccib, A.M.De Girolamoc, F. Gentile,"Modelling soil erosion in a mediterranean watershed: Comparison between SWAT and AnnAGNPS models," in Environmental Research, vol. 166, pp.363-376,October 2018.

11. Raju Narwade \& Dr. Shrikant Charhate "Integrated RUSLE and GIS Approach for Estimating Soil Erosion of Watershed in Karjat" Hydro18, 23 International Conferences on Hydraulics, Water Resources and Coastal Engineering at National Institute of Technology, Patna,19-21 December 2018

12. S. Tarul, T. Praveen, N. Bhaskar, V. Garg in conference paper "water budget component estimation using satellite data and hydrological modeling”, IIT Madras,4-6 December 2013.

13. Sandra George, Sathian, K.K., "Assessment of water balance of watershed using SWAT model for Water resource management". International Journal of Indian Science and technology, 5(4), 177184, April 2016.

14. Sharma, Tarul and Thakur, pravin and Nikam, Bhaskar and Garg, Vaibhav, "Water budget components estimation using satellite data andhydrological model",2013.

15. Tao Can, Chen Xiaoling, Lu Jianzong, Phillip W. Gassman, Sauvage Sabine, Sanchez Perez Jose-Miguel,“Assessing Impact Of Different Land Use Scenarios on Water Budget of Fuhe River,China using SWAT model Int J Agric \& Biol Eng, 8(3): pp. 95-109, 2015.

16. Vivek Kumar, Raju Narwade and Kartik Nagarajan, "Determination of water budget of lower Godavari River Basin using GIS and SWAT, International journal for research in Engineering application and management,vol 5,issue-07, Oct-2019.

17. Zhixiang lu, Songbing zou, Hinglang Xiao, Chunmiao Zheng, Zhenliang Yin, Weihua Wang, in“" Comprehensive Hydraulic Caliberation of SWAT and water balance analysis in mountainous watetsheds in Northwest China", vol 78-82, pp. 76-85,2015.

18. Global Weather Data for SWAT (https://globalweather.tamu.edu)

19. Central Ground Water Board (http://cgwb.gov.in/watershed/cdgodavari.html)

20. India-WRIS (http://tamcnhp.com/wris/\#/waterData)

21. Earthexplorer-USGS (https://www.usgs.gov/earthexplorer-0)

22. HydroSHEDS (https://hydrosheds.org) 


\section{AUTHORS PROFILE}

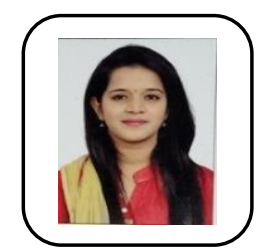

Akshata Mestry, Billing Engineer, VASCON, also pursuing Masters in Construction Engineering amd Management from Pillai HOC College of Engineering and Technology which is affiliated to University of Mumbai, her research is in the field of water resources with application of Remote Sensing and Geographical information System. She has completed her Bachelors in Civil Engineering also from University of Mumbai. Her area of intrest are in the field of Remote Sensing and Geographic Information System. She has participated in International Workshop on Application of Remote Sensing and Geographic Information System for Sustainable Development in Engineering, which had members including IEI, ISRS and ASTER. She has also worked as a lecturer in Pillai HOC Polytechnic, affiliated to MSBTE for two years and participated in many FDP's and STTP's and is presently working as a Billing engineer in VASCON Engineers Ltd, Vidyavihar, Mumbai.

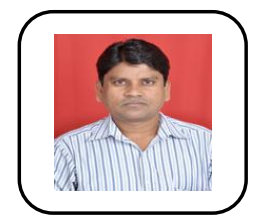

Raju Narwade, Head of Departmnet, Pillai HOC College of Engineering and Technology, Rasayani is currently pursuing Ph.D. in Civil Engineering (research in the field of water resources with application of Remote Sensing and GIS) from University of Mumbai. He completed his Masters in Structural Engineering from University of Mumbai and Bachelors in Civil Engineering from Shri Guru Gobind Singhji Institute of Engineering and Technology (SGGSIE\&T), Nanded. He has published more than 25 technical papers in International Journals and conferences along with few in national journals/conferences. His area of interest are in the field of Remote Sensing and Geographic Information System. He is Life member of various international and National professional bodies like ISTE , ISH , ISRS , IAHS , IWWA , ASTR , ISPRS. He also a Recognized Post Graduate Supervisor, University of Mumbai, Treasurer, Indian Society of Remote Sensing (ISRS), Mumbai Local Chapter, Selected for Government and ISRO Sponsored Training Programme at Indian Institute of Remote Sensing, Dehradun, Examiner for Post Graduate, Savitribai Phule Pune University, Member of Syllabus Revision Committee for Concrete Technology, Structural Analysis-I and II Courses of UG Program in Civil Engineering, University of Mumbai.

Member of Syllabus Revision Member for Total Quality Management in Construction and Construction safety, Energy Conservation Techniques in Building Construction Courses of PG program in Civil Engineering, University of Mumbai, Joint Chief Conductor of Examination, University of Mumbai (Second Half-2012), Member of panel of examination for Maharashtra Public Service Commission (MPSC) (2004), Subject expert for Engineering Mechanics in Sasmira Institute of Man- Made Textile, Worli, Mumbai. (2000-2001).

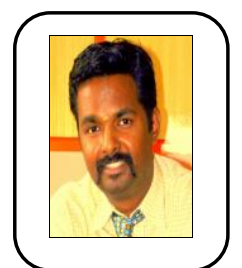

Karthik Nagarajan, Associate Professor, Pillai HOC College of Engineering and Technology, Rasayani is currently pursuing Ph.D. in Civil Engineering (research in the field of water resources with application of Remote Sensing and GIS) from University of Mumbai. He completed his Masters in Structural Engineering from University of Mumbai and Bachelors in Civil Engineering from Pune University in the year 2009 and 2002 respectively. He has published technical papers in 18 International Journals and 12 international conferences along with few in national journals/conferences .His area of interest are in the field of Remote Sensing and Geographic Information System . He is Life member of various international and National professional bodies like ISTE, ISH, ISRS, IAHS , IWWA , IAHR , ISPRS. He has received BEST Network Institute Coordinator Award (IIRS ISRO Outreach Program )For Contribution towards promoting Geospatial Technology and its applications in Year 2018 and Certificate of Appreciation as Network Institute Coordinator Award (IIRS ISRO Outreach Program )For Contribution towards promoting Geospatial Technology and its applications in Year 2017 IIRS ,Indian Space Research Organisation (ISRO). He also bagged First Prize $\left(14^{\text {th }}\right.$ Maharashtra State Inter University) Avishkar Research Convention 2019-20 organized by University of Mumbai on January 2020 and Silver Medal $\left(14^{\text {th }}\right.$ Maharashtra State Inter-Collegiate/Institute/Department) Avishkar Research Convention 2019-20 organized by University of Mumbai on January 2020. Being a Network coordinator of IIRS ISRO Outreach Program he is also the Secretary of Indian Society of Remote Sensing , Mumbai Chapter. 